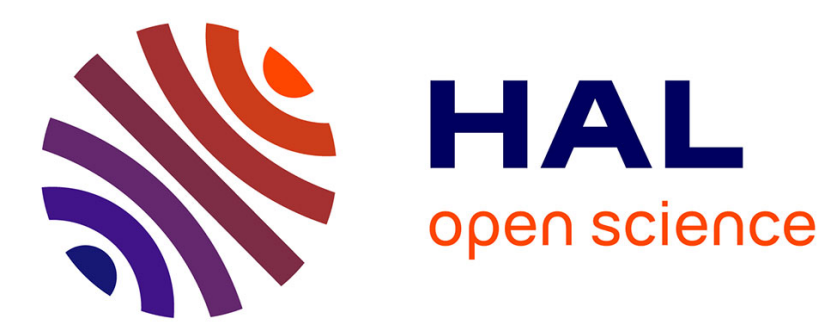

\title{
Service Economies and Complexity
}

Benoît Desmarchelier

\section{To cite this version:}

Benoît Desmarchelier. Service Economies and Complexity. Handbook of Service Science, Volume II, 2018. hal-02393045

\section{HAL Id: hal-02393045 \\ https://hal.science/hal-02393045}

Submitted on 4 Dec 2019

HAL is a multi-disciplinary open access archive for the deposit and dissemination of scientific research documents, whether they are published or not. The documents may come from teaching and research institutions in France or abroad, or from public or private research centers.
L'archive ouverte pluridisciplinaire HAL, est destinée au dépôt et à la diffusion de documents scientifiques de niveau recherche, publiés ou non, émanant des établissements d'enseignement et de recherche français ou étrangers, des laboratoires publics ou privés. 


\title{
Service Economies and Complexity
}

\author{
Benoît Desmarchelier ${ }^{1}$
}

\begin{abstract}
The economic literature on services has for a long time been dominated by an industrialist bias which considers services as unproductive. This point of view was progressively replaced by a more positive integrative framework that takes into account possibilities of non-technological innovations. However, this framework does not constitute a theory of the growth of services and business services. We show the proximity between the integrative framework and the complex systems, and we argue that theories of the dynamics of such systems offer promising explanations for these two phenomena. In a systemic perspective, services are catalysts -i.e. actors who increasingly complexify the economic system - by taking part to various production and innovation processes at the same time.
\end{abstract}

\section{Introduction}

In economic theory, the advent of tertiary economies was either ignored or observed with fear. Services have indeed, for a long time, been characterized by a set of a priori characteristics - for instance unproductivity or immateriality - that makes empirical investigations challenging (Djellal and Gallouj, 2008) and theoretical ones rather pessimistic with regards to the future of growth of service economies (Baumol, 1967). ${ }^{2}$ Yet, these economies remain the most successful ones in the world, as they are the biggest producers and exporters of agricultural, industrial and tertiary products (Hausmann and Hidalgo, 2013), they attract the majority of international students in higher education (OECD, 2014) and they rank on top of virtually all indicators of success (wealth, number of patents, political stability, etc.).

The debate on the contribution of services to economic growth has been characterized by three successive approaches: "industrialist", "service-oriented", and "integrative" (Gallouj, 1994; Gallouj and Savona, 2009). In the industrialist perspective, services are seen as "stagnant" activities - i.e. their productivity remains constant through time, which explains their growing importance in terms of employment (Baumol, 1967). The service-oriented point of view emphasizes services-specific innovations: services do innovate, but the immaterial nature of their

\footnotetext{
${ }^{1}$ Assistant Professor in Economics, The University of Lille, France, benoit.desmarchelier@univ-lille.fr This chapter draws on a research carried out within the COVAL project (European Commission, Horizon 2020 funding number 770356).

${ }^{2}$ See Delaunay and Gadrey (1992) for an account of this pessimistic opinion in the history of economic thought.
} 
output makes it difficult to measure these innovations (Djellal and Gallouj, 2008). The integrative view overcomes the dichotomy between services and manufacturing by merging the two previous approaches into a single framework (Gallouj and Weinstein, 1997; de Vries, 2006, Bryson and Daniels, 2010).

The industrialist theory is deductive: it is based on a set of assumptions - for instance that services are unproductive - from which is derived a series of conclusions, notably the tertiarisation of economic activities. At the opposite, contributions in the integrative perspective are mainly empirical and conceptual, without the ambition to propose an alternative story about the tertiarisation process. Also, a common limitation between these three sets of contributions is that they are not producing a theory of the growth of employment in business services. Standard explanations for this new trend include decisions of industrial firms to externalize their service operations, and the need to access specific knowledge which is delivered by business services (Beyers and Lindahl, 1996).

Our objective in this chapter is to show the proximity between the integrative framework and the theory of complex (adaptive) systems. We argue that existing theories of the evolution of such systems offer a fruitful framework for understanding the growth of services as well as the emergence of intertwining dynamics between goods and services. This conceptual proposition echoes recent contributions in economics and service science advocating for a systemic representation of economic activities (Holland and Miller, 1991; Arthur, 1993; 2015; Basole and Rouse, 2008; Rouse and Basole, 2010; Farmer and Foley, 2009).

The rest of the chapter is organized as follows: a first section reviews and assesses the technologist theory about the growth of services and introduces the integrative framework as a complex system. The second section reviews some important contributions on the dynamics of complex adaptive systems and explains how they can enrich the explanatory power of the integrative approach.

\section{From Dichotomy to Integration}

\subsection{The Unbalanced Growth Model and its Limitations}

The model of unbalanced economic growth proposed by Baumol (1967) formalizes the standard view in economics about the growth of the service sectors in employment and national production. This model relies on a set of three hypotheses:

(i) Labor productivity is constant in services, while it is growing in industry. Service activities are thus qualified as "technologically stagnant" while manufacturing ones are seen as "progressive" (See also Fourastié, 1949). 
(ii) Similar wages in service and manufacturing jobs (due to perfect labor mobility in a competitive world). It follows that wages in service sectors grow at the same rate as the labor productivity in industry.

(iii) High income-elasticity and low price-elasticity for service products.

The relatively high productivity growth in manufacturing sectors combined with a relatively low income-elasticity for industrial goods generate an outflow of workers from these industries, while the opposite forces - low productivity gains and high income-elasticity - create job opportunities in services in the meantime. It follows that the labor force gradually shifts from manufacturing to services. Consequences for economic growth are rather negative. The most obvious one is that, since an increasing amount of the labor force is employed in stagnant activities, the growth of national production is slowing down over time. Secondly, the share of services in the Gross Domestic Product (GDP) only increases due to a price effect, while their share in the real GDP remains constant. Indeed, a similar wage between sectors imposes that service workers are paid a wage rate greater than what they deserve in terms of productivity; costs and prices are thus rising exponentially in service sectors, making difficult any rise of service production above the rhythm of the overall economic growth. This phenomenon was famously labelled as the "cost disease" (Baumol and Bowen, 1966).

Confronted with the emergence of information technologies, Baumol et al. (1985) enhance this dual conception between progressive industry and stagnant services by proposing a third class of sectors: the asymptotically stagnant services. Activities that fall into this category share characteristics with the two former sectors: they are services - thus stagnant by nature - but at the same time they make use of progressive inputs "in fixed proportions" (p. 807). This dual nature allows these services to exhibit high productivity gains in the short run, while they become progressively stagnant over time due to the aforementioned "cost disease". According to these authors, activities in communication and broadcasting are a good example of asymptotic stagnancy: thanks to their progressive inputs (ex. electronic transmission devices) they exhibit the highest productivity gains among all sectors in 1947-76 in the United States, with an annual growth rate in labor productivity of $5.42 \%$ (p. 809). If the theory is verified, then this rate should decrease over time. We test this prediction by computing the compound annual growth rate (CAGR) of labor productivity by sector in the United States in recent years. For the sake of comparison with Baumol et al. (1985), we use the same (but updated) data source, i.e. the Real Value Added by Industry and the Full-Time Equivalent Employees by Industry provided by the U.S. Bureau of Economic Analysis. ${ }^{3}$

\footnotetext{
${ }^{3}$ These data can be found at the following webpage:

https://bea.gov/iTable/iTable.cfm?ReqID=51\&step=1\#reqid=51\&step=2\&isuri=1

Last access: Feb. 92017.

We use the real value added to remove potential price effects in services, and also because value added is a measure of production net from intermediate consumption.
} 
Results are provided in Table 1. From 1998 to 2015, we observe that both services and industry exhibit very heterogeneous performances. Like in Baumol et al. (1985), service sectors experience both the worst and the highest productivity growth. Interestingly, "broadcasting and telecommunication" are still one of the highest performers with a CAGR of $6.573 \%$. This obviously contradicts the hypothesis of asymptotic stagnancy, since this rate of growth is even higher than the one reported by Baumol et al. (1985) for the period 1947-76. Overall, all activities related with information perform very well. Also, some services traditionally labelled as "stagnant", like finance and insurance, real estate, waste management or wholesale trade are experiencing a higher growth of their labor productivity than the average of the economy.

It is well known that the growth of the labor productivity is slowing down since 2004 in most developed economies - including in the United States (Syverson, 2017; Byrne et al., 2016). In order to identify the role of services in this slowdown, we divide 1998-2015 into two sub-periods in Table 1: 1998-2004 and 2004-2015. The slow-down is clear since the compound annual growth rate of labor productivity of the whole economy decreases from $2.294 \%$ to $0.941 \%$. Most sectors experience a large decrease in the rate of growth of labor productivity between the two sub-periods. In line with this general tendency, several high performing services in 1998-2004, like data processing or publishing, are experiencing a significant slow-down (from $12.748 \%$ to $4.169 \%$, and from $6.572 \%$ to $2.375 \%$, respectively), but they remain nonetheless important drivers of economic growth, as their productivity growth rates remain significantly higher than the one of the entire economy.

All these observations are casting doubt on the empirical validity of the standard economic theory about the rise of service sectors. Indeed, stagnant services can actually be progressive, and asymptotically stagnant ones remain the most progressive over time.

Another limitation of the unbalanced growth model is that it only includes consumer services, while there also exists many business service activities in the real world. As an example, warehousing or data processing in Table 1 are very likely inputs of other production processes. In the context of rapid growth of employment in business services within advanced economies, Oulton (2001) enhances Baumol's framework with intermediate services. He finds that, even if business services exhibit a low productivity growth, ${ }^{4}$ the rise of employment in these activities paradoxically favors an acceleration of the national productivity growth rate. The intuition behind this result is as follows: any rise of productivity in a business service is directly benefiting to this activity and also indirectly to its clients' production processes. If we consider that business services have clients in many other sectors, then any small increase in their productivity indirectly fosters productivity growth of the economy as a whole. In a similar line of thought, Desmarchelier at al. (2013) build an agent-based model of economic growth in which knowledge intensive business

\footnotetext{
${ }^{4}$ See for instance the low productivity growth of "management of companies and enterprises" in Table 1.
} 
services (KIBS thereafter) foster the accumulation of human capital and the growth of labor productivity in all other sectors of the economy.

Table 1: Compound Annual Growth Rate of Labor Productivity by Sector of Activity in the United States from 1998 to 2015.

\begin{tabular}{|c|c|c|c|c|}
\hline & \multirow[b]{2}{*}{ Sectors ${ }^{5}$} & \multicolumn{3}{|c|}{ CAGR (in\%) } \\
\hline & & 1998-2015 & 1998-2004 & 2004-2015 \\
\hline \multirow{7}{*}{ 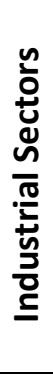 } & Agriculture, forestry, fishing, and hunting & 2.898 & 7.286 & 0.581 \\
\hline & Mining & 1.040 & -1.051 & 2.198 \\
\hline & Utilities & 0.749 & 2.131 & 0.003 \\
\hline & Construction & -1.138 & -1.373 & -1.010 \\
\hline & Manufacturing & 3.874 & 6.908 & 2.255 \\
\hline & Durable goods & 5.072 & 8.028 & 3.494 \\
\hline & Nondurable goods & 2.414 & 5.334 & 0.856 \\
\hline \multirow{22}{*}{ 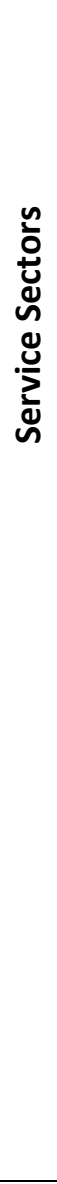 } & Wholesale trade & 1.862 & 3.406 & 1.029 \\
\hline & Retail trade & 1.025 & 2.052 & 0.469 \\
\hline & Transportation and warehousing & 0.322 & 0.809 & 0.058 \\
\hline & Information & & & \\
\hline & Publishing industries, except internet (includes software) & 3.837 & 6.572 & 2.375 \\
\hline & Motion picture and sound recording industries & 2.938 & 3.121 & 2.838 \\
\hline & Broadcasting and telecommunications & 6.573 & 7.077 & 6.299 \\
\hline & Data processing, internet publishing, and other information services & 7.120 & 12.748 & 4.169 \\
\hline & Finance and insurance & 2.127 & 3.666 & 1.297 \\
\hline & Real estate and rental and leasing & 1.858 & 1.093 & 2.278 \\
\hline & \multicolumn{4}{|l|}{ Professional, scientific, and technical services } \\
\hline & Legal services & -0.787 & 0.153 & -1.296 \\
\hline & Computer systems design and related services & 3.005 & 3.619 & 2.672 \\
\hline & Miscellaneous professional, scientific, and technical services & 0.563 & 0.929 & 0.364 \\
\hline & Management of companies and enterprises & 0.116 & 0.081 & 0.136 \\
\hline & Administrative and waste management services & 2.407 & 3.622 & 1.750 \\
\hline & Educational services & -0.457 & -0.207 & -0.593 \\
\hline & Health care and social assistance & 0.176 & 0.669 & -0.091 \\
\hline & Arts, entertainment, and recreation & 0.217 & -0.298 & 0.498 \\
\hline & Accommodation and food services & -0.101 & 2.044 & -1.253 \\
\hline & Other services, except government & -1.377 & -2.270 & -0.886 \\
\hline & Government & 0.287 & 0.271 & 0.295 \\
\hline \multicolumn{2}{|r|}{ Whole Economy (i.e. Gross domestic product) } & 1.416 & 2.294 & 0.941 \\
\hline
\end{tabular}

\footnotetext{
${ }^{5}$ The activities labelled as "services" in this Table are those producing chiefly immaterial products. The distinction with industrial sectors is artificial, since most industrial firms offer at least some services to their clients (Bryson and Daniels, 2010; Campbell-Kelly and Garcia-Swartz, 2007). However, we keep it as a reference, for discussing the validity of the industrialist thesis regarding the unproductivity of services.
} 


\subsection{The Integrative Approach as a Complex System}

A lesson from the previous section is that the clear distinction between industry and services found in Baumol (1967) progressively disappears, as some services include progressive (or industrial) inputs (Baumol et al., 1985), and some industries make use of (business) services in their production processes (Oulton, 2001). Observing that "service functions now comprise 70-80 per cent of the 'production costs' of most manufacturing companies", Bryson and Daniels (2010, p. 83) even propose to replace the term service economy by the one of "manuservice economy" ( $p$. 90).

In front of this progressive intertwining between industry and services, Gallouj and Weinstein (1997) propose to replace the production function, used in most economic models, by a system of interacting characteristics and actors that can be applied to both service and industrial activities (see Figure 1). In this system, a product is defined as a set of service characteristics [Y], obtained through the combination of technical characteristics [X], which can be tangible or intangible, and competencies of the provider [C] and of its client [C']. In Baumol (1967) and Oulton (2001), economic agents can only innovate by improving their technologies, and thus raising labor productivity. This hypothesis is disadvantaging service activities, because their output is difficult to measure (Djellal and Gallouj, 2008). The integrative framework, on the other hand, is flexible enough to account for a wide variety of innovations (Gallouj and Weinstein, 1997): radical, when all vectors $\left\{[\mathrm{Y}],[\mathrm{X}],[\mathrm{C}],\left[\mathrm{C}^{\prime}\right]\right\}$ are transformed; incremental, when the innovation adds some characteristics to at least one vector; improvement, when the performance of a characteristic is improved; recombinative, when the interactions between characteristics of the products are modified; formalization, when the innovation consists in codifying some characteristics of the product or the production process; and finally ad hoc, when an unanticipated modification occurs to at least one characteristic of the product, due to the involvement of the client in the innovation process. 


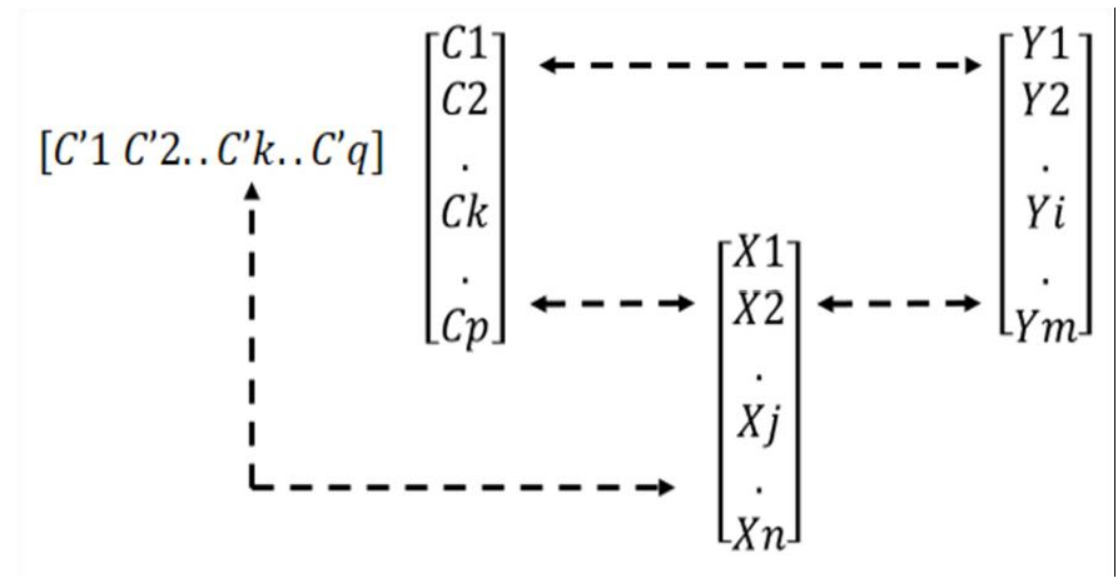

Figure 1: Product Representation (adapted from Gallouj and Weinstein, 1997)

Despite its numerous qualities, the framework proposed by Gallouj and Weinstein (1997) cannot replace the model of unbalanced economic growth (Baumol, 1967) as a theory of tertiarisation of economic activities. Indeed, the integrative approach does not postulate differences between goods and services, nor do they formulate hypothesis about consumers' behaviors. Many contributions in service science conceptualize service activities as complex systems (Sporher et al., 2007), either on the production side (Basole and Rouse, 2008), organizational side (Rouse et al., 2009; Rouse, 2007), or on the output side (Rouse and Basole, 2010). Similarly, Gallouj and Weinstein's framework can be considered as a complex system.

There is no unique definition of complexity (Rosser, 2009), but there is nonetheless a core element in all existing definitions: complexity usually refers to "systems with multiple elements adapting or reacting to the pattern these elements create" (Arthur, 2009 p.12). The notion of system refers to a set of relationships - or a network - existing between these elements. The system gets complex when elements' interactions allow for the emergence of an aggregate pattern, and when elements react to this pattern. Also, complexity is not a binary state, and thus the distinction between complex and simple systems is not always easy to make.

Kauffman' NK model (1993; 1995) illustrates and quantifies the degree of complexity of a system. The model takes the form of a network of $N$ nodes - originally standing as genes - and $K$ inputs, or relations, between them. ${ }^{6}$ If, for instance, $K=5$ then each node is linked with five others in the system. In this specific case, any change in one node will affect five other nodes, generating a series of cascades of reactions in the other nodes with which they are linked. In this framework, a system is simple if $K=0$, and it gets increasingly complex for higher values of $K$. The system is chaotic when $K=N$.

\footnotetext{
${ }^{6}$ The NK model attributes a measure of performance to the different possible combinations of nodes. For the sake of simplicity and clarity, we abstract from such a measure in this chapter.
} 
The production process displayed in Figure 1 can be considered as a variant of the NK model in which each component of the vectors $[\mathrm{Y}],[\mathrm{X}],[\mathrm{C}]$, and [C'] is a node, with $K$ links directed towards other nodes in the system. The more a product - good or service - is complex, the higher the parameter $K$. If $\mathrm{K}>0$, then any innovation affecting one characteristic of the product will have a cascade of consequences on other characteristics, with a relatively unpredictable final outcome. Also, if a business service intervenes in another production process - like in Oulton's model - then we have to consider the formation of a larger network, with two imbricated systems of vectors $\left\{[\mathrm{Y}],[\mathrm{X}],[\mathrm{C}],\left[\mathrm{C}^{\prime}\right]\right\}$ and with relations of hierarchy between them. Hence, the economy as a whole is not anymore a collection of independent production functions, but a large system composed of numerous interacting and imbricated sub-systems. In this context, the study of complex systems dynamics could provide a relevant framework for understanding the emergence of services, and their progressive intertwining with industry.

\section{Services in Complex Systems Dynamics}

The integrative framework applies to both industry and services. All economic activities are thus complex systems. In this section, we start by questioning how this complexity arises, and what is specific about the role of services in complex systems. In a second part, we explain how agents'

behaviors in complex economic systems can foster the growth of services, as well as their progressive mixing with industry.

\subsection{Services in the Evolution of Complexity}

Wolfram's computational experiments on cellular automata (2002) provide a good starting point for understanding how complexity can arise from simple interactions. A cellular automaton is a low dimensional system - often composed by one or two dimensions - in which each component can take a limited number of states - for instance components can be black or white. The state of a particular component changes through time depending on the states of its neighbors. Figure 2 displays an example of cellular automaton based on the product representation proposed by Gallouj and Weinstein (1997). In this example, the cellular automaton is a system of four components $(\mathrm{N}=$ 4), named for convenience $\mathrm{Ck}, \mathrm{C}^{\prime} \mathrm{k}, \mathrm{Xj}$ and $\mathrm{Yi}$. In the simplest case, each of these components can appear in two states - for instance, 1 or 0 - and thus the system offers $2^{4}=16$ combinations. If each component can take three states, then the number of potential combinations becomes $3^{4}=$ 81. It is important to note that not all of these combinations are possible when there exist constraints, or links, between the components of the system. In Figure 2, each component has two links $(K=2)$, such that any change in $C k$ will affect $Y i$ and $C^{\prime} k$, and thus also $\mathrm{Xj}$. Here, there are many possibilities of retroactions on $\mathrm{Ck}$ itself from the rest of the system, hence the final outcome of this chain of events is difficult to foresee. 


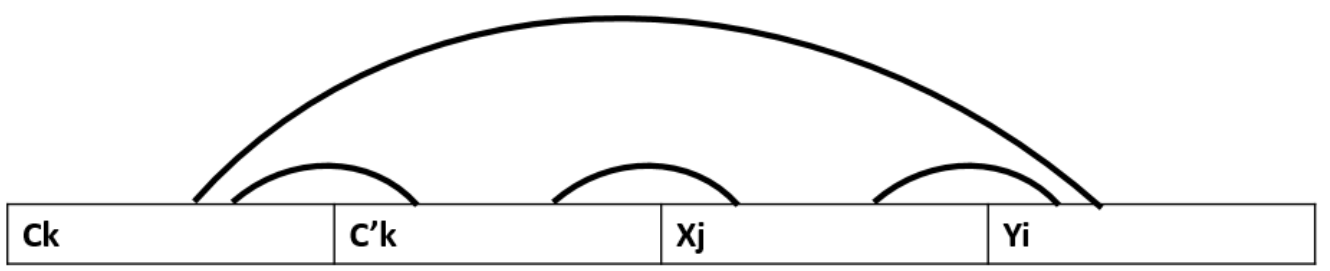

Figure 2: Gallouj and Weinstein 's model (1997) as a cellular automata

Figure 3 provides a more concrete example of the evolution of a cellular automaton. The top row of the figure corresponds to the initial condition. Here, the central cell is black, while all others are white. Wolfram then poses the following rule of evolution (called "rule 30"): if a given cell and its right-hand neighbor are both white, then the cell takes the color of its left-hand neighbor in the following time step. If this condition is not met, then the cell takes the color which is the opposite of its left-hand neighbor. In Figure 3, the evolution of this system over time is shown in the subsequent rows. With the terminology used for the NK model, we can say that $N$ is the number of cells, and $K=2$, since each cell is linked with its two immediate neighbors.

We observe in the figure that this simple system succeeds at generating random, unpredictable, patterns. ${ }^{7}$ This randomness is not present in the initial conditions, nor in the rule of evolution, since this later is deterministic. It is something new that emerges from the interactions between cells. As in the NK model, increasing $K$ generates more complexity, or more unpredictable and rich aggregate patterns. This example illustrates how a system like the one proposed by Gallouj and Weinstein (1997) can evolve in an unpredictable manner through innovations or interactions with the rest of the economy. In this perspective, it is striking to observe a similar movement of tertiarisation in all developed and developing economies. Indeed, this common pattern is more coherent with the existence of deterministic forces, than with randomness. Can we find an explanation for this growth of services in the laws of evolution of complex systems?

7 This "rule 30" can actually even been used as a random number generator (see Wolfram, 2002 p. 317). 


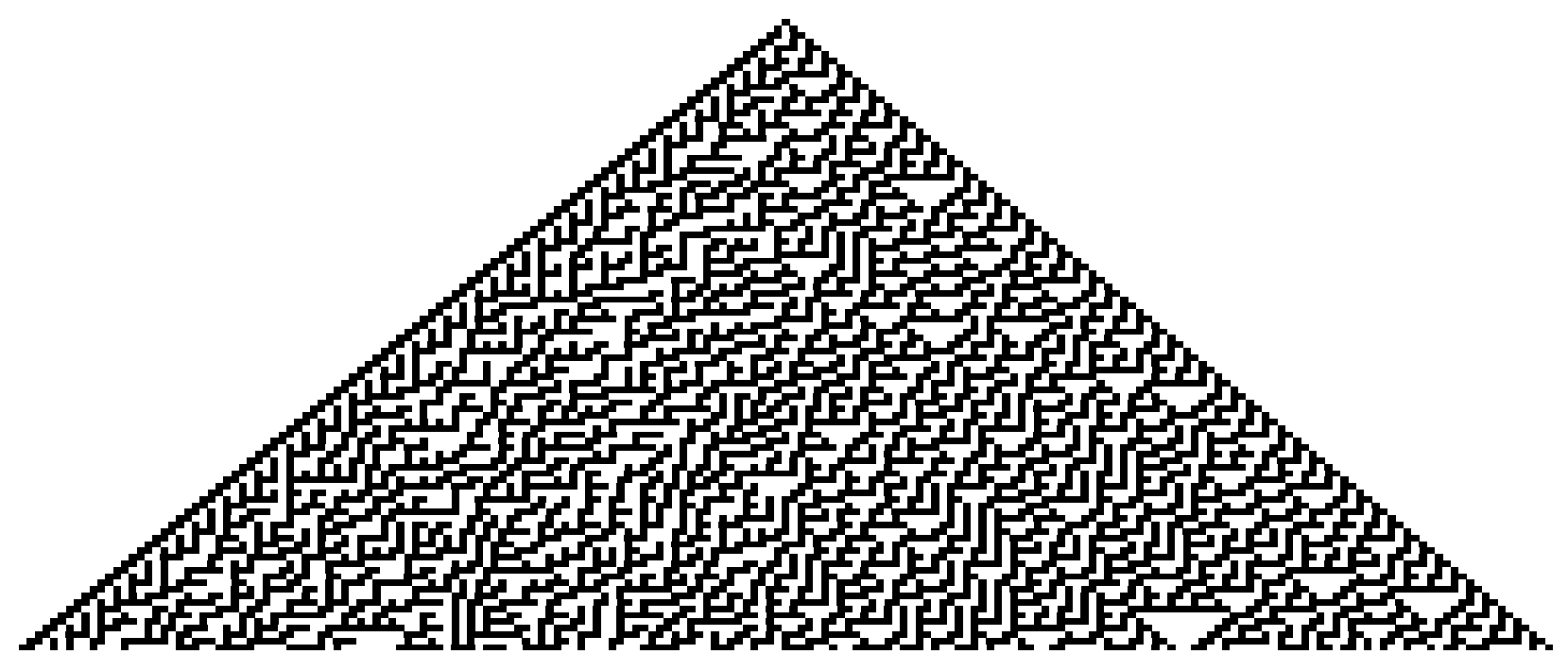

Figure 3 Cellular Automaton, "rule 30", adapted from Wolfram (2002)

In Wolfram's experiments, the number of links $\mathrm{K}$ between the components of the system is constant. However, in natural systems the number of links per component often increases over time through the action of a specific type of molecules - the catalysts - which are elements that "significantly increase the rate at which a chemical reaction happens, without being consumed" in this reaction (Hordijk, 2013 p. 878). Using the terminology introduced with the NK model, these catalysts increase the ratio $\mathrm{K} / \mathrm{N}$. In random networks, a phase transition occurs when $\mathrm{K} / \mathrm{N}=0.5$ (Erdõs and Rényi, 1960). Above this threshold, random networks quickly switch from a collection of small and separated networks to a large network that includes most of the nodes N. Similarly, at this threshold, complex biological systems become "autocatalytic" - i.e. able to create novelties in a self-sustained manner (Kauffman, 1993; 1995). In a sense, developed economies can be qualified as autocatalytic systems as they display a self-sustained economic growth, and they perpetually create new products, activities and technologies (Kauffman, 2011).

Andersson and Andersson (2017) use this threshold property of networked systems to explain the emergence of the "first logistical revolution" in Europe that started at around the year 1000. They conceptualize Medieval Europe as a set of $N$ cities, linked to each other by some trade routes. When the number of routes is relatively small, only few cities are connected to few others. However, above a certain threshold, investing in a new route allows to connect whole clusters of cities together, creating immediately a new cluster of interconnected cities - and thus a market of unprecedented size.

Two criteria enter in the definition of a catalyst element: (i) this element is acting at increasing the connectivity between other elements of the system, and (ii) it does not perish in the resulting reactions - and thus it can continue its linking activity. In this sense, firms can be thought as catalysts: they increase the connectivity between inputs of the economic system (labor, capital and natural resources) and they survive from the production process. Interestingly, with the fall of socialist economies, the twentieth century proved that such catalysts are a necessary condition for 
perpetual growth. In general terms, any human being can act as a catalyst, although it is not necessarily his "raison d'être", contrary to companies.

Services, as a type of economic activity, qualify as catalyst. Indeed, a service can be defined as "an operation of transformation of an element $\mathrm{C}$, owned or used by a consumer (or client, or user), often in relation with this later, but without generating the production of a good likely to circulate economically independently from its support C" (Gadrey, 1992 p. 17). Such activities are thus linking components of the economic system - i.e. a client and an element $\mathrm{C}$ - while at the same time transforming the state of at least one of these elements. There is a marked difference with industrial firms in the sense that the element being transformed does not necessarily need to be material. As a consequence, services can be considered as a more general form of catalyst, and thus as a more powerful engine of economic growth than industrial firms. Most of the firms are not providing purely a service nor do they produce purely a good (Bryson and Daniels, 2010); our intention is thus not to oppose goods and services, but to highlight that services are probably more useful for economic growth than predicted by the industrialist approach.

An illustration of the role of services as catalyst can be found in Desmarchelier et al. (2016), who look at their position in the innovation network of the aerospace cluster located in Belgium. Figure 4 displays this innovation network in its 2006, 2007, 2008, and 2009 configurations. White nodes represent industrial firms and the black ones are services. The links represent the existence of scientific collaboration between the actors, and the size of a node is proportional to its number of connections in the network. The more an actor is central in the network, the bigger is its corresponding node. Compared with the NK framework, the distribution of links among actors is not uniform, since nodes have different sizes. We observe that, in four years, the most central actors in this network are knowledge services - mainly universities, especially the Université de Liège, (noted Ulg in Figure 4) and the Université Catholique de Louvain (UCL), as well as training and research centers, see for instance Cenaero. Thanks to their participation in various research projects at the same time, these services allow for the emergence of a single innovation network i.e. they transform otherwise separated sub-networks into a large network regrouping most of the actors of the cluster. As such, any newcomer in this cluster could easily have access to partners and knowledge involved anywhere in the cluster. This small-world property of the innovation network can foster the emergence of new innovations and it makes the cluster attractive for newcomers. Table 2 reports the number of actors $(N)$ and the number of links $(K)$ in the cluster. We observe that $K$ increases faster than $N$, which implies a higher $K / N$ ratio, and thus higher innovation opportunities over time.

Table 2: Evolution of the Number of Links (K) and Actors (N) in the Belgian Aerospace Cluster from 2006 to 2009 (adapted from Desmarchelier et al., 2016)

\begin{tabular}{|l|l|l|l|}
\hline & K & N & K/N \\
\hline $\mathbf{2 0 0 6}$ & 55 & 15 & 3.67 \\
\hline $\mathbf{2 0 0 7}$ & 298 & 44 & 6.77 \\
\hline $\mathbf{2 0 0 8}$ & 353 & 52 & 6.78 \\
\hline
\end{tabular}


One could argue that the central position of knowledge services in this innovation network is sector specific or country specific. After all, national innovation systems display significant differences between each other (Lundvall, 1988; Niosi et al., 1992). However, there is extensive empirical evidence supporting the instrumental role of universities in the location of firms and the development of clusters in high technology industries. For instance, Audretsch et al. (2005) find that technology-intensive firms in Germany tend to locate close to universities in order to benefit from knowledge spillovers. Grossetti (2001) explains that the early developments of research and teaching programs related with electricity at the University of Grenoble triggered the emergence of an innovation system in the city of Grenoble, transforming it into a leader in the country in computer science and electronics. Similarly, Feldman (2003) argues that the basic research carried out in American universities motivates the location decisions of firms operating in biotechnologies. There are thus reasons to believe that the central role of services in the Aeronautics cluster in Belgium is no exception.

The systemic perspective reveals that services can contribute to foster economic growth independently of their own performance in terms of productivity growth. Indeed, the most central nodes in Figure 4 are universities and research and training centers, while Table 1 reported (in the case of the United States) that education services had even a negative productivity growth rate. 


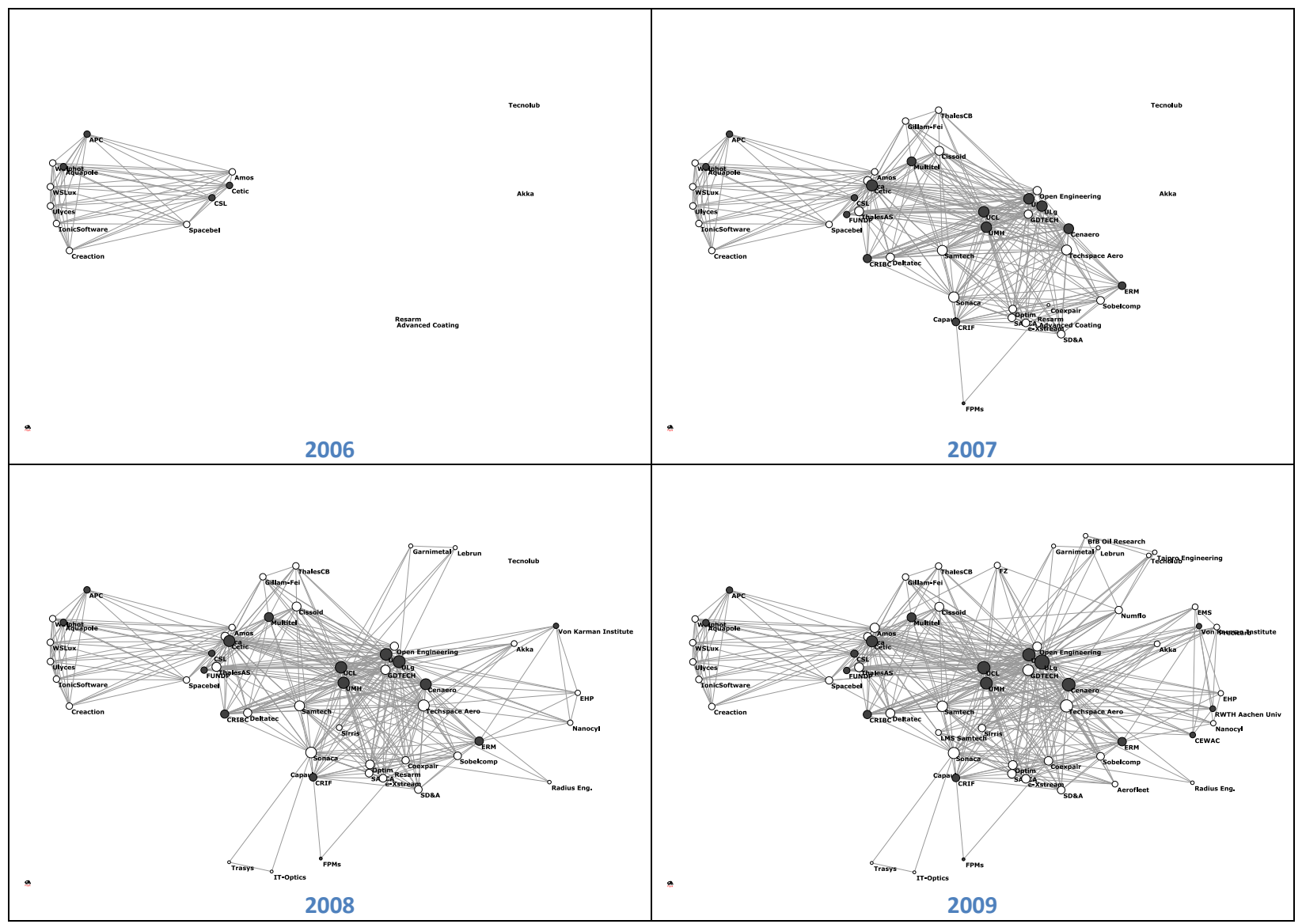

Figure 4: Innovation network of the Belgian aerospace cluster in 2006, 2007, 2008, and 2009. White nodes represent industrial actors, and black ones stand for services (adapted from Desmarchelier et al., 2016)

\subsection{Systems Complexification as a Theory of Economic Tertiarisation}

Compared with natural and artificial systems, catalysts in economic and social systems have the specificity of being purposeful agents (human beings or organizations). It is thus difficult to theorize services' role as catalyst through a conceptual framework that does not involve human action. In this perspective, the adaptive complex systems (or agent-based systems) stand as a necessary refinement for understanding services' actions in the economy. Similarly, Farmer and Foley (2009) argue that such models are needed for guiding the economic policy in a complex and uncertain world.

For Holland and Miller (1991), economies are not only complex, but also adaptive. ${ }^{8}$ They define complex adaptive systems by three characteristics. First, they are composed by a "network of interacting agents" (p. 365). The concept of agent is flexible, as it can be adapted to systems with

\footnotetext{
${ }^{8}$ For an account of the origin of the conceptualization of economies as complex adaptive systems, the interested reader can refer to Arthur (2015).
} 
various degrees of aggregation. For instance, in the case of industrial clusters, interacting agents are innovative firms, public and private research centers, universities and venture capitalists, while in Andersson and Anderson's study of the logistical revolution (2017), agents can be European cities. Also, complex adaptive systems exhibit an aggregate behavior, whose dynamics can be thought as autonomous due to the numerous interactions between agents. Finally, such a system is adaptive when "the actions of the agent in its environment can be assigned a value (performance, utility, payoff, fitness, or the like), and the agent behaves so as to increase this value over time" (Holland and Miller, 1991, p. 365). This definition does not require a specific hypothesis on agents' computing capabilities: they pursue a well-defined objective - for instance they can be profitseeking - but without necessarily knowing how to achieve the best possible outcome with regards to this objective.

In developed capitalist economies, profit stands as the main driver of agents' actions. An example of how individual search for profit transforms agents into catalysts can be found in Hughes's study of the evolution of technological systems (1987). In his work, the catalyst agents - called the "system builders" (p. 46) - are the engineers and the managers. ${ }^{9}$ They are acting at improving the load factor of the system that they are managing, ${ }^{10}$ because higher load factors imply higher returns on investment, thus higher profits. In the case of electric systems, increasing the load factor requires to make the system's output smoother through time, for instance by diversifying the populations of users and by developing the interconnections between power plants. By doing so, the managers are acting as catalysts as they increase the ratio $K / N$ of the electric system.

In more general terms, agents can act as catalysts in three different ways, labelled "growth in coevolutionary diversity", "structural deepening”, and "capturing software” (Arthur, 1993; 2015).

(1) "Growth in coevolutionary diversity" (Arthur, 2015 p. 145). At the microeconomic level, this type of action corresponds to agents' progressive specialization. This occurs when profitseeking agents see business opportunities in new market niches. In aggregate terms, this leads to the emergence of hierarchies and input-output relations between economic sectors, cities, regions or countries (Pumain, 2006). In this sense, growth in coevolutionary diversity is not specific to services. Also, collapses of coevolutionary diversity are always possible, as the appearance of new products or technologies can render existing ones obsolete.

(2) "Structural Deepening" (Arthur, 2015 p. 148). In this perspective, agents act as catalysts by modifying their own structure. In the economic world, firms have gained in structural depth by developing the multi-divisional form ${ }^{11}$ for taking advantage of opportunities of economies of scale

\footnotetext{
${ }^{9}$ Interestingly, "management of companies and enterprises" is among the worst performers in terms of productivity growth in Table 1.

${ }^{10}$ The load factor is "the ratio of average output to the maximum output during a specified period" (Hughes, 1987 p. 65)

${ }^{11}$ In organization studies, the multidivisional form refers to the organization of firms' activities in segmented departments, each one being in charge of the production and commercialization of a specific product line.
} 
(Chandler, 2005). Like for coevolutionary diversity, collapses can occur. For instance, big multidivisional firms are nowadays progressively replaced by smaller networked firms (Chandler, 2005; Rouse et al., 2009; Baumol and Schramm, 2010).

(3) "Capturing Software" (Arthur, 2015 p. 152). "This is the taking over and 'tasking' of simpler elements by an outside system for its own (usually informational) purpose" (p. 152). Arthur takes the example of the electrons: engineers and scientists have progressively learned to "task" them through electronics in order to perform a variety of activities. The outside system - engineers and scientists in this case - has discovered, learned, and codified the "grammar" or the "set of operational rules" (p. 153) governing the elements which are taken over - here the electrons. Most technologies evolve through the tasking of simpler systems by more complex ones (Arthur, 2009). In the biological world, colonies of bacteria are living in - and tasked by - human bodies. Another example of capturing software in social systems can be found in the birth of legal codes. In this case, the outside system is the jurist community, which is creating and enforcing laws. Progressively, jurists have regrouped and systematized laws in the form of legal codes, that can be used - or tasked - by many agents (the jurists, but also lawyers, or firms) in order to solve or avoid cases of disputes.

The variety of these examples suggests that the capturing software mechanism is pervasive in evolving systems. In human-made systems, the capture and tasking of simpler elements is conscious, and it requires many service activities: the identification and codification of elements to be tasked can be done through $R \& D$ and consultancy activities, while the implementation of the tasking requires monitoring services, as well as other supporting services (schools, universities, hospitals, lawyer cabinets, justice courts...), depending on the nature of the system that needs to be tasked. For instance, the progressive tasking of electrons required research activities, as well as schools and universities for spreading the knowledge about the principles of electricity. Hence, the capturing software mechanism can be a powerful engine driving the demand for services, independently of their characteristics in terms of labor productivity or prices.

Besides, the previous example on the role of services in the shaping of the Belgian innovation network in aeronautics shows that the relationship between services and complexity is not unidirectional. Not only service activities emerge through the complexification of the economic system, but they also contribute to make the system increasingly more complex. For instance, Gallouj (2002) indicates that KIBS are specialized in processing and transferring knowledge to their clients. Using the terminology of the capturing software, KIBS companies represent the outside system, which transforms tacit and/ or codified knowledge from the client and other sources into an operational system, executable (or tasked) by the client firm. KIBS are thus economic agents which are specialized in proposing capturing software services to their clients. As a consequence, services are both a product and a producer of complexification of the economic system through capturing software. 


\section{Conclusion}

This chapter has started by questioning the industrialist assumption of the unproductivity of services and the traditional distinction between goods and services. Figures of the U.S. productivity growth rate at the sector level reveal that some services are structurally among the best performers in terms of productivity growth, in particular those making use of significant technological inputs. Goods and services are thus more mingled than postulated by the theory.

The integrative approach of service production and innovation is more convincing on a descriptive basis, but it is lacking in terms explanatory power. Stressing the intellectual proximity between this approach and complex systems, we argue that existing theories about the dynamics of these systems can enrich the integrative approach with a theory of the growth of service sectors. Under this framework, the emergence of services and their progressive intertwining with industry can be explained as both a consequence and a cause of the complexification of economic systems. Profitseeking economic agents act as catalysts - i.e. they increase the intensity of interactions between economic agents and components (technologies, natural resources, etc.) - through various strategies (specialization, structural deepening and capturing software) that generate the appearance of new activities - including services - which further complexify the economic system.

Developing a complex integrative framework and providing empirical evidence of the role of services as system complexifiers represents a promising research agenda in the economics of services. It could provide an alternative to productivity measures for assessing services' contributions to economic growth.

\section{References}

Andersson A.E., Andersson D.E. (2017), Time, Space and Capital, Edward Elgar.

Arthur W.B. (1993), “Why Do things become More complex?”, Scientific American, May

Arthur W.B. (2009), "Complexity and the Economy”, in Rosser B.J. (Eds.) Handbook of research on Complexity, Edward Elgar, Cheltenham, pp. 12-21.

Arthur W.B. (2015), "On the evolution of complexity", in Arthur W.B. (Ed.) Complexity and the Economy, Oxford University Press, New York.

Audretsch D.B., Lehmann E.E., Warning S. (2005), "University spillovers and new firm location”, Research Policy, vol. 34 pp. 1113-1122. 
Basole R.C., Rouse W.B. (2008), “Complexity of service value networks: conceptualization and empirical investigation”, IBM Systems Journal, vol. 47 pp. 53-70.

Baumol W.J. (1967), "Macroeconomics of unbalanced growth: the anatomy of an urban crisis", American Economic Review, vol. 57 pp.415-426.

Baumol W.J., Blackman S., Wolff E. (1985), “Unbalanced growth revisited: asymptotic stagnancy and new evidence", American Economic Review, vol. 75 pp. 806-817.

Baumol W.J., Bowen W. (1966), Performing arts: the economic dilemma. Twentieth Century Fund, New York.

Beyers W.B., Lindahl (1996), "Explaining the demand for producer services: is cost-driven externalization the major factor?”, Papers in Regional Science, vol. 75 pp. 351-374.

Bryson J.R., Daniels P.W. (2010), "Manuservice economy”, in Maglio P.P., Kieliszewski C.A. and Spohrer J.C. (eds.), Handbook of Service Science, Springer, New York, pp. 79-104.

Byrne D.M., Fernald J.G., Reinsdorf M.B. (2016), "Does the United States have a productivity slowdown or a measurement problem?”, Brookings Papers on Economic Activity, Spring, pp. 109182.

Campbell-Kelly M., Garcia-Swartz D.D. (2007), "From products to services: the software industry in the Internet era", Business History Review, vol. 81 pp. 735-764.

Chandler A.D. (2005), “Commercializing High-Technology Industries”, Business History Review, vol. 79 pp. 595-604.

De Vries E. (2006), "Innovation in services in networks of organizations and in the distribution of services", Research Policy, vol. 35 pp. 1037-1051.

De Vries E.J. (2006), "Innovation in services in networks of organizations and in the distribution of services", Research Policy, vol. 35 pp. 1037-1051.

Delaunay J.C., Gadrey J (1992), Services in Economic Thought, Kluwer Academic Publishers

Desmarchelier B., Djellal F., Gallouj F. (2013), "Knowledge intensive business services and long term growth", Structural Change and Economic Dynamics, vol. 25 pp. 188-205. 
Desmarchelier B., Djellal F., Gallouj F. (2016), "KIBS and the Dynamics of Industrial Clusters: a Complex Adaptive Systems Approach", in J. Ferreira, M. Raposo, C. Fermandes, M Dejardin (Eds.) Knowledge Intensive Business Services and Regional Competitiveness, Routledge, London, pp. 48-82.

Djellal F., Gallouj F. (2008), Measuring and Improving Productivity in Services: Issues, Strategies and Challenges. Edward Elgar, Cheltenham.

Erdõs P, Rényi A. (1960), "On the evolution of random graphs", Publications of the Mathematical Institute of the Hungarian Academy of Sciences, vol. 5 pp. 17-61.

Farmer J.D., Foley D. (2009), “The economy needs agent-based modelling”, Nature, vol. 460 pp. 685-686.

Feldman M. (2003), "The locational dynamics of the US biotech industry: knowledge externalities and the anchor hypothesis", Industry and Innovation, vol. 10 pp. 311-328.

Fourastié J. (1949), Le grand espoir du XXème siècle. Presse Universitaire de France, Paris.

Gadrey J. (1992), L'économie des services, La Découverte, Paris.

Gallouj F. (1994), Economie de l'innovation dans les services, L'Harmattan, Paris.

Gallouj F. (2002), "Knowledge-intensive business services: processing knowledge and producing innovation", in Gadrey J., Gallouj F. (Eds.) Productivity, Innovation and Knowledge in Services, New Socio-Economic Approaches, Edward Elgar, Cheltenham, pp. 256-284.

Gallouj F., Savona M. (2009), "Innovation in services: a review of the debate and a research agenda", Journal of Evolutionary Economics, vol. 19 pp. 149-172.

Gallouj F., Weinstein O. (1997), "Innovation in Services”, Research Policy, vol. 26 pp. 537-556.

Grossetti M. (2001), "Genèse de deux systems urbains d'innovation en France : Grenoble et Toulouse”, Réalités industrielles. Annales des mines, Février, pp. 68-72.

Hausmann R., Hidalgo C., Bustos S., Coscia M., Simoes A., Yildirim M.A. (2013), The Atlas of Economic Complexity, Mapping Paths to Prosperity. MIT Press.

Holland J.H., Miller J.H. (1991), "Artificial adaptive agents in economic theory", American Economic Review, vol. 81, pp. 365-370. 
Hordijk W. (2013), "Autocatalytic sets: from the origin of life to the economy", BioScience, Vol. 63 pp. 877-881.

Hughes T.P. (1987), “The evolution of large technological systems”, in Bijker W.E., Hughes T.P., Pinch T. (Eds.) The Social Construction of Technological Systems. New Directions in the Sociology and History of Technology, MIT Press, pp. 51-82.

Kauffman (2011), "Economics and the collectively autocatalytic structure of the real economy", 13.7 Cosmos and Culture, National Public Radio. (last access, 9 August 2017: www.npr.org/blogs/13.7/2011/11/21/142594308/economics-and-the-collectively-autocatalyticstructure-of-the-real-economy)

Kauffman S. (1993), The Origins of Order. Self-Organization and Selection in Evolution, Oxford University Press.

Kauffman S. (1995), At Home in the Universe, Oxford University Press.

Lundvall B.A. (1988), "National systems of innovation: towards a theory of innovation and interactive learning", in Lundvall B.A. (Ed.) The Learning Economy and the Economics of Hope, Anthem Press, pp. 85-106.

Niosi J., Bellon B., Saviotti P., Crow M. (1992), "Les systèmes nationaux d'innovation : à la recherche d'un concept utilisable", Revue Française d'Economie, vol. 7 pp. 215-250.

OECD (2014), Education at a Glance 2014: OECD Indicators. OECD Publishing.

Oulton N. (2001), "Must the growth rate decline? Baumol's unbalanced growth revisited", Oxford Economic Papers, vol. 53 pp. 605-627.

Pumain D. (2006), "Alternative explanations of hierarchical differentiation in urban systems", in Pumain D. (Ed.), Hierarchy in Natural and Social Sciences, Springer, pp. 169-222.

Rosser B.J. (2009), "Introduction”, in Rosser B.J. (Ed.) Handbook of research on Complexity, Edward Elgar, Cheltenham, pp. 4-11.

Rouse W.B. (2007), "Complex engineered, organizational and natural systems", Systems Engineering, vol. 10 pp. 260-271. 
Rouse W.B., Basole R.C. (2010), "Understanding complex product and service delivery systems", in Maglio P.P., Kieliszewski C.A. and Spohrer J.C. (eds.), Handbook of Service Science, Springer, New York, pp. 461-480.

Rouse W.B., McGinnis L.F., Basole R.C., Bodner D.A., Kessler W.C. (2009), "Models of complex enterprise networks", Second International Symposium on Engineering Systems, MIT Cambridge, Massachusetts, June 15-17.

Schramm C.J., Baumol W.J. (2010), "Foreword", in Maglio P.P., Kieliszewski C.A. and Spohrer J.C. (eds.), Handbook of Service Science, Springer, New York, pp. ix-xi.

Spohrer J.C., Maglio P.P. (2010), "Toward a science of service systems: value and symbols", in Maglio P.P., Kieliszewski C.A. and Spohrer J.C. (eds.), Handbook of Service Science, Springer, New York, pp. 157-194.

Syverson C. (2017), "Challenges to mismeasurement explanations for the US productivity slowdown”, Journal of Economic Perspectives, vol. 31 pp. 165-186.

Wolfram S. (2002), A New Kind of Science, Wolfram Media, Inc. 
